\title{
1000HPK TRAINING FOR CADRES AND PREGNANT WOMEN TO PREVENT STUNTING IN THE BUNGURSARI HEALTH CENTER WORK AREA OF TASIKMALAYA CITY IN 2020
}

\author{
Melsa Sagita Imaniara), Rissa Nuryuniarti, Sri Wahyuni Sundari, Wiatanti, and \\ Hikmatunisa
}

Program Studi D 3 Kebidanan, Universitas Muhammadiyah Tasikmalaya, Tasikmalaya, Indonesia

a)Corresponding Author: melsa.sagita@umtas.ac.id

\begin{abstract}
Bungursari Health Center in 2018 had stunting toddlers as many as 219 out of 1140 toddlers (19\%). In 2018 there were 28 stunted toddlers with chronic malnutrition conditions, as well as pregnant women who experienced KEK as many as 23 people, as many as $56 \%$ of mothers who breastfeed exclusively and mothers as much as $74 \%$ have provided complementary breast milk since the age of 4 months and many mothers provide breast milk companion food with a menu that does not meet the STANDARD 4 quadrant WHO. This community service aims to carry out 1000 HPK mentoring training for cadres so that there is an increase in the knowledge and skills of cadres in escorting 1000 HPK so as to prevent stunting. Community Service training of 1000 HPK followed by 30 cadres for 2 days involving expert sources in their fields, namely the Head of Health Center, Midwife Coordinator, Nutritionist and Promkes and Midwife with the expertise of breastfeeding counselors, training is carried out face-to-face question and answer discussion methods and practicums. The results of the activities obtained are in the improvement of the knowledge and skills of cadres in controlling 1000 HPK.
\end{abstract}

Key words: 1000 HPK, Stunting, Cadre Training

\section{INTRODUCTION}

Stunting is one of the nutritional problems experienced by toddlers in the world, in 2013 about 16 million children experienced it, until 2017 a number of $22.2 \%$ or about 150.8 million toddlers in the world experienced stunting (de Onis and Branca, 2016). In 2018 as many as 8 million Indonesian children experienced growth disorders, the prevalence of stunting in Indonesia in 2018 was $37.2 \%$, meaning that 1 in 3 Indonesian children experienced Stunting (Ministry of People's Welfare of the Republic of Indonesia, 2013). Stunting is a condition in which toddlers have a length or height less when compared to age.. The impact caused is that children get sick easily, cognitive abilities are reduced, when old people are at risk of developing dietary related to diet, unbalanced body functions, not maximal posture as adults, and experiencing economic losses (Akombi et al., 2017) (Cetthakrikul et al., 2018).

Stunting can occur as a result of malnutrition especially during the first 1000 days of life (HPK), 270 days during pregnancy plus the first year 365 days and the second year 365 days. A thousand days is a golden opportunity to form a healthy and smart child. One way to prevent 
stunting is the fulfillment of nutrition and health services to pregnant women (Aguayo and Menon, 2016). Prevention of stunting is carried out through national strategies, one of which is the priority target of pregnant women and children aged $0-2$ years or households 1,000 HPK with priority interventions, namely specific and sensitive nutritional interventions.

This condition becomes a joint responsibility, especially the faculty of health sciences obstetrics study program, one of which pays attention to the obstetrics care of infants and toddlers in health problems, especially stunting events. Health services of pregnant women and children aged 0-2 years, one of which is obtained through Posyandu activities managed by cadres, the introduction of the $1000 \mathrm{HPK}$ strategy as an important stunting prevention is understood by cadres as the front line on maternal and child health targets.

Bungursari Health Center as one of the areas of Tasikmalaya City and a partner of the Faculty of Health Diploma III Midwifery Study Program in 2018 has stunting toddlers as many as 219 out of 1140 toddlers (19\%). In 2018 there were 28 stunted toddlers with chronic malnutrition conditions, as well as pregnant women who experienced KEK as many as 23 people, as many as $56 \%$ of mothers who breastfeed exclusively and mothers as much as $74 \%$ have provided complementary breast milk since the age of 4 months of baby and many mothers provide breast milk companion food with a menu that does not meet the STANDARD 4 quadrant WHO either home-made or instant. Thus it is very important that there are 1000HPK training activities for cadres and pregnant women to prevent stunting in the bungursari health center work area. The purpose of community service training of 1000 HPK for cadres is to improve the knowledge and skills of cadres in escorting 1000 HPK so as to prevent stunting in Bungursari Health Center.

\section{METHOD}

The method of implementing activities in this community service program is carried out with several 5 stages as follows: (1) Mapping is kia problem analysis in Bungursai Health Center, obtained high stunting cases. due to the lack of information about 1000 HPK, and the results of the questionnaire showed low levels of knowledge and skills, (2) Mediation with Bungursari Health Center includes licensing and adjutant description of activity materials as well as speakers and participation of 30 cadres in activities, (3) Formulation of Problems and Solutions provided, namely conducting community service activities through training activities for cadres and pregnant women in controlling 1000 HPK and preventing stunting. The activities are divided into 2, namely 1000HPK training for cadres and pregnant women, (4) Problem Solving Method conducts 1000 HPK training activities to improve the knowledge and skills of cadres in escorting 1000 HPK to prevent stunting, (5) Implementation and Implementation Phase using lecture methods, discussions, shared practices and online mentoring. The practice of 1000 HPK training for packed cadres involves experts in their fields, namely the head of health center, midwife coordinator, nutritionist and health promotion and licensed breastfeeding counselor ofinasia. The implementation was held for 2 days, namely 27-28 November 2020 at Pustu Cibunigeulis Bungursari with a total of 30 cadres. 
This activity lasted for 2 days, namely the implementation date of November 26-27, 2020 at the cibunigeulis pustu location, followed by 30 participants, namely cadres and pregnant women in the third trimester, the activity was carried out by fulfilling the requirements of the Covid 19 prevention health protocol with $3 \mathrm{M}$, namely wearing masks, maintaining distance and avoiding crowds so that this activity was divided into 2 sessions in each day and one session consisted of 15 people. The first day of material exposure includes 1. explanation of the 1000HPK 2 training program. Nutrition during pregnancy 3. Exclusive breast milk and 4. MP-BREAST MILK processing, day 2 of 1000 HPK simulation practice training in pregnant women includes exclusive breastfeeding and MP-breast milk processing by cadres.

Peserta First pre-tests are performed to measure knowledge about 1000 HPK, then systematically given materials and practice of simulating 1000 HPK training. This form of training is active, so cadres and pregnant women immediately practice after exposure to the material.. One of them is how to practice position and attachment in breastfeeding so that in time the mother of birth can immediately breastfeed her baby and successfully breastfeed exclusively for 6 months. Then participants engaged in the direct processing of MP-BREAST MILK after being given exposure to the source. Completed the training conducted post test, and the result there was an increase in the score regarding 1000 HPK from cadre participants and pregnant women.

\section{DISCUSSION}

Stunting is a chronic malnutrition problem caused by a lack of nutritional intake for a long time, resulting in impaired growth in children i.e. the child's height is lower or shorter (dwarf) than the standard age (de Onis and Branca, 2016). The critical points that must be considered during the first 1000 days of life are, the period in the womb 280 days, the age of $0-6$ months 180 days, the age of $6-8$ months 60 days, the age of 8-12 months 120 days, and the age of 1224 months 360 days. In this period there is a very rapid brain growth, which supports the entire process of growth of the child perfectly. This period is important because malnutrition in the golden period cannot be corrected in later life (Ford et al., 2018).

Maternal knowledge about nutritional intake in children from pregnancy to age 2 years is still found low, of course this will affect the attitude and behavior of the mother in controlling 1000 HPK and preventing stunting (Wahyono and Putri, 2013). The smooth production of breast milk is influenced by many factors such as, frequency of breastfeeding, birth weight, maternal age and parity, stress and acute illness, IMD, breast care, contraceptive use and nutritional status. Hypnobreastfeeding that is routinely done during pregnancy has been shown to increase the percentage of mothers successfully breastfeeding early in birth. The availability of smooth breast milk in nursing mothers will help the baby grow and develop properly according to who's recommendations..

In addition to causing failure to grow, in the first 1000 days of life, babies who do not have enough breast milk can experience diarrhea and penumonia. Some of the efforts that can be made during pregnancy to prepare for breastfeeding are hypnobreastfeeding, yoga in pregnancy and taking breastfeeding classes together with a breastfeeding counselor. 


\section{CONCLUSIONS And RECOMMENDATIONS}

1000 HPK training activities for important cadres are carried out in an effort to produce 1000 HPK ambassadors so as to prevent stunting. Exclusive breast milk is the main nutrient in infants less than 6 months and can prevent stunting in children later, the provision of MP-BREAST MILK must refer to according to WHO and Ministry of Health standards..

\section{ACKNOWLEDGMENTS}

The author thanked the Faculty of Health Sciences, University of Muhammadiyah Tasikmalaya and LPPM for providing financial support to community service activities. As well as the Puskesmas and Midwife Bungursari Tasikmalaya Village.

\section{REFERENCES}

Aguayo, V. M. and Menon, P. (2016) "Stop stunting: Improving child feeding, women's nutrition and household sanitation in South Asia," Maternal and Child Nutrition. Blackwell Publishing Ltd, 12, pp. 3-11. doi: 10.1111/mcn.12283.

Akombi, B. J. et al. (2017) "Stunting, wasting and underweight in Sub-Saharan Africa: A systematic review," International Journal of Environmental Research and Public Health. MDPI AG. doi: 10.3390/ijerph14080863.

Cetthakrikul, N. et al. (2018) "Childhood stunting in Thailand: when prolonged breastfeeding interacts with household poverty," BMC pediatrics. BioMed Central, 18(1), p. 395. doi: 10.1186/s12887-018-1375-5.

Ford, N. D. et al. (2018) "Exposure to improved nutrition from conception to age 2 years and adult cardiometabolic disease risk: a modelling study," The Lancet Global Health. Elsevier Ltd, 6(8), pp. e875-e884. doi: 10.1016/S2214-109X(18)30231-6.

Kementerian Kesejahteraan Rakyat Republik Indonesia (2013) "Kerangka Kebijakan: Gerakan Nasinal Percepatan Perbaikan Gizi (Gerakan 1000 Hari Pertama Kehidupan)."

de Onis, M. and Branca, F. (2016) "Childhood stunting: A global perspective," Maternal and Child Nutrition, 12, pp. 12-26. doi: 10.1111/mcn.12231.

Wahyono, T. Y. M. and Putri, D. S. K. (2013) "Faktor Langsung dan Tidak Langsung yang Berhubungan dengan Kejadian Wasting pada Anak Umur 6 - 59 Bulan di Indonesia Tahun 2010," Media Penelitian dan Pengembangan Kesehatan, 23(3). doi: 10.22435/mpk.v23i3.3280.110-121. 


\section{ATTACHMENT}



Figure 1. Cadre Training

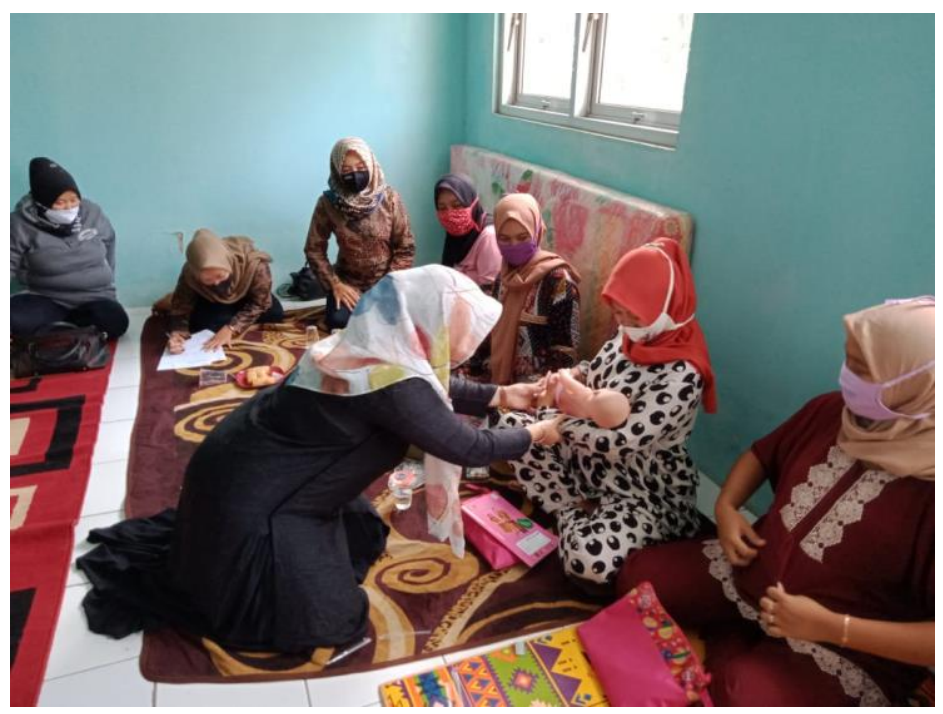

Figure 2. Assistance of Pregnant Women with Breastfeeding Counselors

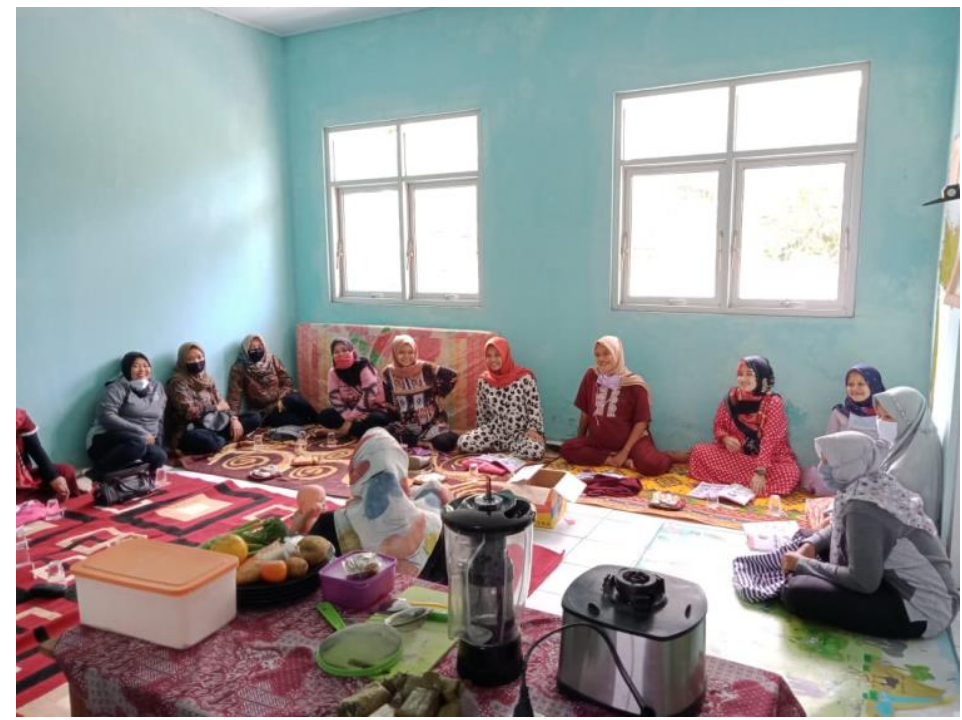


Figure 3. Breast Milk Companion Food Cadre Training 